\title{
Pengaruh pengelolaan agroekosistem terhadap kelimpahan kutu loncat jeruk Diaphorina citri Kuwayama (Hemiptera: Liviidae)
}

\author{
The effect of agroecosystem management on the abundance of \\ Asian citrus psyllid Diaphorina citri Kuwayama (Hemiptera: Liviidae)
}

\author{
M. Zuhran ${ }^{1,2}{ }^{*}$, Gatot Mudjiono ${ }^{1}$, Retno Dyah Puspitarini ${ }^{1}$ \\ ${ }^{1}$ Fakultas Pertanian, Universitas Brawijaya \\ Jalan Veteran Malang 65145, Indonesia \\ ${ }^{2}$ Balai Pengkajian Teknologi Pertanian Kalimantan Barat, Badan Penelitian dan \\ Pengembangan Pertanian, Kementerian Pertanian \\ Jalan Budi Utomo No. 45, Pontianak 78241, Indonesia
}

(diterima Januari 2021, disetujui Maret 2021)

\begin{abstract}
ABSTRAK
Kutu loncat jeruk (KLJ) Diaphorina citri Kuwayama merupakan masalah serius pada tanaman jeruk karena menularkan penyakit huanglongbing (HLB). Praktik budi daya tanpa memperhatikan kompleksitas agroekosistem sering menyebabkan agroekosistem lebih sesuai untuk proliferasi serangga hama dan kurang ramah bagi musuh alami. Penelitian ini bertujuan mempelajari efektivitas pengelolaan agroekosistem dibandingkan dengan pertanian konvensional dalam mengendalikan KLJ. Selain itu, pengaruh kedua perlakuan terhadap keanekaragaman dan kelimpahan musuh alami KLJ serta kejadian dan intensitas HLB juga dipelajari. Pengelolaan agroekosistem terdiri atas tindakan preventif dan responsif. Tindakan preventif dilakukan melalui sistem tanam polikultur, penanaman refugia dan legum penutup tanah, penyediaan jalur rumput, pemberian kapur pertanian, pupuk organik dan anorganik, pemangkasan jeruk secara intensif, pemeliharaan parit drainase, serta pengendalian gulma secara mekanis. Tindakan responsif merupakan pengendalian jangka pendek yang dilakukan ketika kelimpahan KLJ mencapai ambang tindakan. Tindakan responsif dilakukan melalui pengendalian hayati ataupun kimiawi. Sementara itu, pertanian konvensional merupakan serangkaian teknik budi daya dan pengendalian hama yang biasa diterapkan petani. Setiap perlakuan masing-masing diterapkan di tiga kebun Jeruk Siam Pontianak Citrus nobilis Lour. var. microcarpa Hassk. Hasil penelitian menunjukkan bahwa pengelolaan agroekosistem lebih efektif mengendalikan populasi KLJ hingga kelimpahannya lebih rendah dan kurang berfluktuasi dibandingkan dengan pertanian konvensional. Selain itu, musuh alami KLJ pada pengelolaan agroekosistem lebih beragam dibandingkan dengan pertanian konvensional. Kelimpahan musuh alami KLJ serta kejadian dan intensitas HLB pada kedua perlakuan tidak berbeda nyata.
\end{abstract}

Kata kunci: Diaphorina citri, musuh alami, pengelolaan agroekosistem

\begin{abstract}
Asian citrus psyllid (ACP) Diaphorina citri Kuwayama is a serious problem in citrus because it transmits huanglongbing (HLB) disease. Agricultural practices without paying attention to the agroecosystem complexity often cause the agroecosystem more suitable for insect pests proliferation and less friendly to natural enemies. The research aims to study the effectiveness of agroecosystem management compared to conventional farming in the ACP control. The effects of both treatments on the diversity and abundance of ACP's natural enemies as well as the incidence and severity of
\end{abstract}

\footnotetext{
*Penulis korespondensi: M. Zuhran. Fakultas Pertanian, Universitas Brawijaya, Jalan Veteran Malang 65145, Indonesia Tel: 0341-551665, 565845, Faks: 0341-560011, Email: zoehran@yahoo.com
} 


\begin{abstract}
HLB were also studied. Agroecosystem management consists of preventive and responsive actions. Preventive action was carried out through a polyculture system, planting refugia and legume cover crop, providing beetle banks, applying lime, applying organic and inorganic fertilizers, citrus pruning intensively, maintaining drainage ditches, and mechanical weed control. Responsive action is short-term control when the abundance of ACP reaches the action threshold. Responsive action was carried out through biological or chemical control. Meanwhile, conventional farming is a series of conventional farming and pest control techniques commonly applied by farmers. Each treatment was applied in three orchards of Siam Orange cv. Pontianak Citrus nobilis Lour var. microcarpa Hassk. The results showed that agroecosystem management was more effective in controlling the ACP population so that its abundance was lower and less fluctuated than conventional farming. ACP's natural enemies in agroecosystem management were also more diverse than conventional farming. The abundance of ACP's natural enemies and the incidence and severity of HLB in the two treatments were not significantly different.
\end{abstract}

Key words: agroecosystem management, Diaphorina citri, natural enemies

\section{PENDAHULUAN}

Kutu loncat jeruk (KLJ) Diaphorina citri Kuwayama, hemipteran yang klasifikasinya telah direvisi dari Famili Psyllidae ke Liviidae (Burckhardt \& Ouvrard 2012), merupakan hama utama pada tanaman jeruk (Yang et al. 2006). Nimfa dan imago mengisap cairan daun sehingga daun menjadi layu kemudian mengering (Wijaya et al. 2012). KLJ lebih memilih mengisap tunas muda sehingga populasinya meningkat sejalan dengan munculnya tunas baru (Sétamou et al. 2016; Tsai et al. 2002).

Kerusakan langsung yang ditimbulkan KLJ sebagai hama umumnya masih dapat ditoleransi tanaman. Namun, kerugian yang lebih besar disebabkan oleh peran KLJ sebagai vektor penyakit huanglongbing (HLB). HLB menyebabkan kehilangan hasil 30-100\% (Iftikhar et al. 2016). Di Asia, KLJ berasosiasi dengan bakteri Liberibacter asiaticus Jagoueix et al. (Rhizobiales: Phyllobacteriaceae) (Bové 2006).

Praktik pertanian modern telah berdampak negatif terhadap musuh alami yang menyebabkan kerentanan tanaman terhadap serangga hama dan penyakit meningkat (Altieri \& Nicholls 2005). Di beberapa kawasan, populasi KLJ yang melimpah diikuti dengan kejadian HLB yang tinggi. Di Pulau Siompu, Kabupaten Buton Selatan, kejadian HLB di dua desa mencapai $56,52 \%$ dan $74,45 \%$ masing-masing dengan kelimpahan KLJ 1,06 dan 4,11 individu/pohon, lebih tinggi dibandingkan dengan kejadian HLB di dua desa lainnya tanpa KLJ, yakni masing-masing 4,45\% dan 6,65\% (Ratu et al. 2020).
Pengelolaan terpadu kebun jeruk sehat (PTKJS) dilaporkan efektif mengurangi kelimpahan KLJ dan menghambat HLB (Endarto et al. 2006). Namun, di beberapa kawasan jeruk seperti Sambas dan Ponorogo, petani belum mengadopsi seluruh komponen PTKJS (Ridwan et al. 2008; Ridwan et al. 2010). PTKJS lebih mudah diterapkan pada pertanaman jeruk yang dikelola secara perkebunan dibandingkan pada kawasan jeruk rakyat yang umumnya sempit dan terpencar (Supriyanto et al. 2010).

Beberapa taktik pengendalian dilaporkan belum efektif mengendalikan KLJ dan HLB. Peningkatan nutrisi tanaman, pemangkasan cabang bergejala, induksi resistensi, termoterapi uap, fitohormon, ataupun aplikasi antibiotik belum mencapai tingkat pengendalian HLB yang tinggi atau tidak layak secara ekonomi untuk diadopsi dalam skala luas (Bassanezi et al. 2020). Eradikasi selektif, eradikasi total, maupun infus antibiotik juga belum berhasil mengendalikan HLB (Nurhadi 2015). Populasi KLJ yang dikendalikan secara terpadu melalui penyaputan dan penyemprotan insektisida, pemupukan berdasarkan rekomendasi, dan pemangkasan pemeliharaan dilaporkan tidak berbeda nyata dengan pengendalian cara petani (Warda \& Asaad 2008).

Resolusi jangka panjang masalah hama hanya dapat dicapai dengan merestrukturisasi dan mengelola sistem pertanian dengan cara memaksimalkan berbagai kekuatan pencegahan (Lewis et al. 1997). Konsep ekologi ini mengoptimalkan sinergitas dengan mendesain ulang agroekosistem yang melibatkan pergeseran hubungan linear ke jaringan hubungan serangga 
hama, musuh alami terkait, dan skema diversifikasi tanaman sehingga sistem pertanian menjadi kurang rentan terhadap ledakan hama (Altieri \& Nicholls 2005). Dalam sistem ini, pencegahan masalah hama dilakukan dengan meningkatkan "kekebalan" agroekosistem dan mengintegrasikan kegiatan pengelolaan hama dengan praktik pertanian lainnya (Mudjiono 2013).

Pengendalian hama melalui pengelolaan agroekosistem merupakan pengendalian hayati yang mengoptimalkan peran musuh alami sebagai faktor pembatas perkembangan herbivora (Nurindah 2006). Strategi pengendalian ini dapat berupa strategi proaktif dan reaktif. Strategi proaktif atau pengendalian melalui teknik budi daya merupakan manipulasi agroekosistem yang membuat sistem pertanian kurang sesuai untuk pembentukan dan proliferasi populasi hama, sedangkan strategi reaktif dilakukan untuk menanggapi situasi hama dengan tindakan jangka pendek (Dufour 2001). Namun demikian, efektivitas konsep ini dalam mengendalikan KLJ belum pernah dilaporkan.

Beberapa praktik budi daya dilaporkan mempengaruhi serangga hama, musuh alami, ataupun penyakit HLB. Lanskap yang lebih kompleks dan dekat dengan habitat semi alami dapat meningkatkan komunitas serangga predator (Elek et al. 2020). Peningkatan keanekaragaman vegetasi, termasuk tanaman berbunga dan legum penutup tanah, dilaporkan dapat meningkatkan keanekaragaman ataupun populasi musuh alami (Daniati et al. 2018; Patt \& Rohrig 2017). Aplikasi pupuk daun, kalium, kalsium, dan silikat serta waktu pemangkasan yang tepat dapat meningkatkan ketahanan tanaman jeruk terhadap infestasi KLJ dan menekan kejadian dan intensitas HLB (Joubert \& Stassen 2000; Pustika et al. 2008; Ramírez-Godoy et al. 2018).

Penelitian bertujuan mempelajari efektivitas pengelolaan agroekosistem dibandingkan dengan pertanian konvensional dalam mengendalikan populasi KLJ. Penelitian ini juga mengkaji pengaruh kedua perlakuan tersebut terhadap keanekaragaman dan kelimpahan musuh alami KLJ serta kejadian dan intensitas HLB.

\section{BAHAN DAN METODE}

\section{Lokasi penelitian}

Penelitian dimulai dari bulan Desember 2019 hingga Mei 2020 di Desa Serumpun Buluh dan Desa Pangkalan Kongsi, Kecamatan Tebas, Kabupaten Sambas. Lokasi ini dipilih karena kelimpahan KLJ dan kejadian HLB yang relatif tinggi (Supriyanto et al. 2017). Penelitian dilaksanakan pada enam kebun Jeruk Siam Pontianak Citrus nobilis Lour. var. microcarpa Hassk (Rutaceae) yang telah berproduksi berumur 4-7 tahun. Varietas ini paling banyak dibudidayakan di Kabupaten Sambas, yakni mencapai 88,5\% pada tahun 2020 (Dinas Pertanian dan Ketahanan Pangan Kabupaten Sambas, data tidak dipublikasikan). Enam kebun jeruk tempat penelitian ini dilaksanakan adalah milik petani dengan populasi jeruk di setiap kebun bervariasi mulai dari 103 hingga 132 pohon dengan luas $1.539-2.018 \mathrm{~m}^{2}$. Kebun-kebun ini berada pada ketinggian 2-4 m dpl.

Curah hujan berfluktusi selama penelitian, namun hampir seragam antar kebun. Rerata curah hujan pada enam kebun penelitian adalah $48 \mathrm{~mm} /$ minggu dengan curah hujan minimum dan maksimum masing-masing 0 dan $121 \mathrm{~mm} /$ minggu. Berdasarkan data BMKG (2020), rerata suhu udara di Kabupaten Sambas selama penelitian berkisar $24,0-29,3{ }^{\circ} \mathrm{C}$ dengan suhu minimum $21,0-25,2{ }^{\circ} \mathrm{C}$ dan maksimum 25,8 $34,4{ }^{\circ} \mathrm{C}$. Sementara itu, rerata kelembapan nisbi harian di Kabupaten Sambas selama penelitian adalah $89,2 \%$ dengan kelembapan nisbi minimum dan maksimum masing-masing $79 \%$ dan $99 \%$.

\section{Rancangan penelitian}

Penelitian terdiri atas dua perlakuan, yaitu pengelolaan agroekosistem dan pertanian konvensional. Pengelolaan agroekosistem meliputi tindakan preventif dan responsif, sedangkan pertanian konvensional merupakan serangkaian teknik budi daya dan pengendalian hama secara konvensional yang biasa diterapkan petani (Tabel 1). Setiap perlakuan diterapkan pada tiga kebun jeruk yang berbeda sehingga secara keseluruhan penelitian ini dilaksanakan pada enam kebun. Ketiga kebun pada masing-masing perlakuan mewakili lingkungan yang berbeda, yaitu kebun 
Tabel 1. Rincian perlakuan pengelolaan agroekosistem dan pertanian konvensional

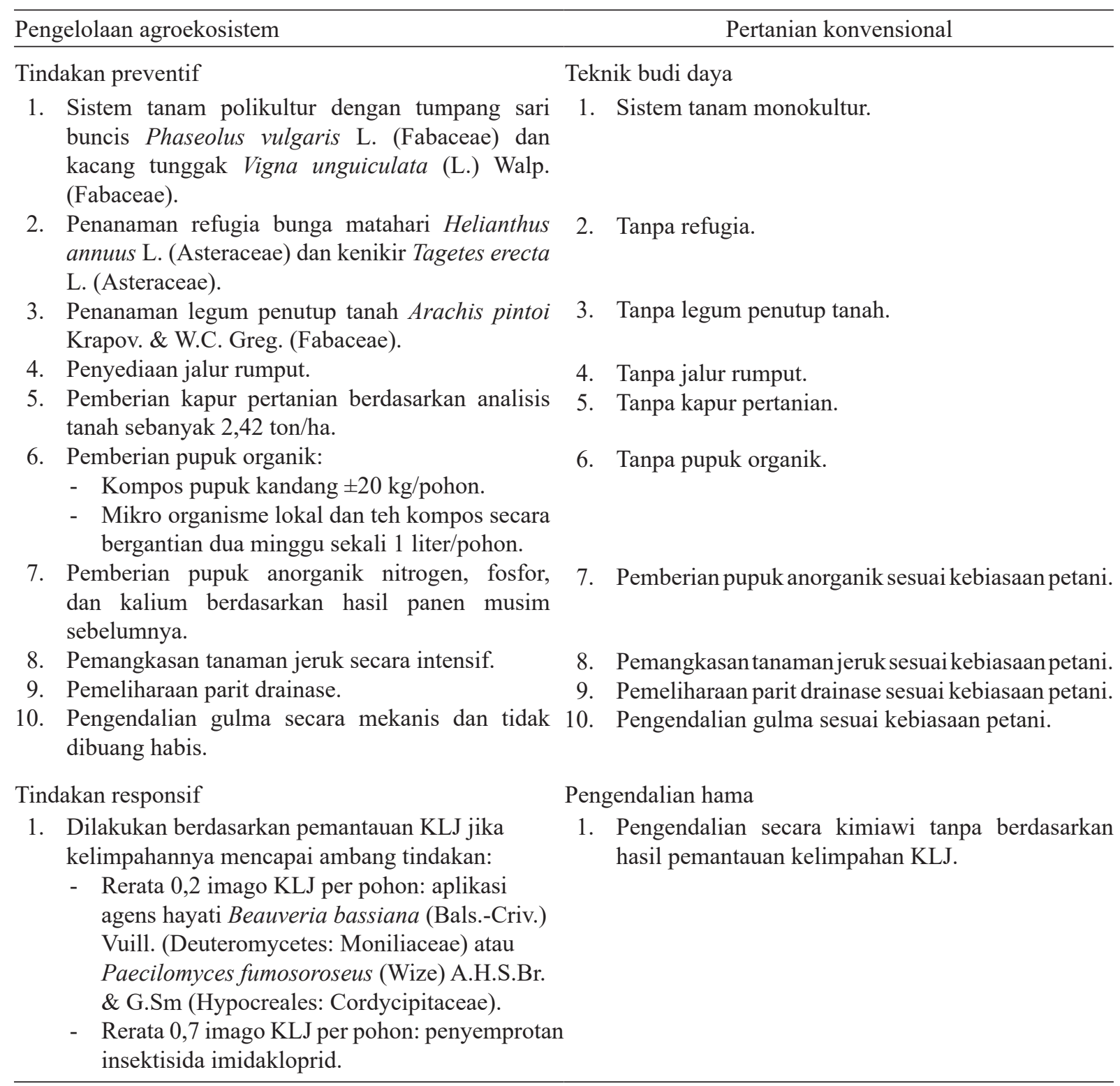

di hamparan kebun-kebun jeruk lainnya, kebun dengan salah satu sisinya berdekatan dengan kebun karet, dan kebun yang berdampingan dengan tanaman padi.

\section{Pengamatan kelimpahan KLJ}

Pengamatan kelimpahan KLJ dilakukan sebelum, selama, dan setelah periode pertunasan jeruk. Pengamatan sebelum pertunasan dilakukan tujuh kali (P1-P7) dari 5 Desember 2019 sampai 25 Februari 2020. Pengamatan selama pertunasan dilaksanakan lima kali (P8-P12) dari 10 Maret sampai 7 April 2020. Sementara itu, pengamatan setelah pertunasan dilakukan dua kali (P13-P14), yakni pada tanggal 22 April dan 5 Mei 2020.
Pengamatan sebelum dan setelah periode pertunasan merupakan pemantauan kelimpahan KLJ yang dilakukan setiap dua minggu sekali. Hasil pemantauan ini menjadi dasar keputusan tindakan responsif pada perlakuan pengelolaan agroekosistem. Pemantauan KLJ sebelum dan setelah periode pertunasan tidak membedakan kategori tunas yang diinfestasi KLJ, sedangkan pengamatan KLJ selama periode pertunasan dilakukan seminggu sekali sesuai perkembangan tunas utama jeruk mulai kategori SI hingga SV (Tabel 2). Selama periode pertunasan, pertumbuhan tunas baru tumpang tindih. Angkatan tunas kategori SI pada pengamatan P8 paling banyak dibandingkan dengan angkatan tunas 
Tabel 2. Kategori tunas jeruk (Arredondo 2009)

\begin{tabular}{lcl}
\hline Kategori & Umur (minggu) & \multicolumn{1}{c}{ Karakteristik fisik } \\
\hline SI & $\leq 1$ & $\begin{array}{l}\text { Tunas baru muncul, masih lembut, tanpa kuncup, berwarna kuning hingga hijau, dan } \\
\text { panjang batang tunas }<1 \mathrm{~cm} .\end{array}$ \\
SII & $1-2$ & $\begin{array}{l}\text { Warna hijau muda pada tunas meluas, daun masih lembut, dan panjang batang tunas } \\
1-2,5 \mathrm{~cm} .\end{array}$ \\
SIII & $2-3$ & $\begin{array}{l}\text { Perluasan daun telah lengkap, daun masih lembut dengan warna hijau muda, dan } \\
\text { panjang batang tunas }<5 \mathrm{~cm} .\end{array}$ \\
SIV & $3-4$ & $\begin{array}{l}\text { Daun telah tua, keras, warna hijau, dan panjang batang tunas }>5 \mathrm{~cm} . \\
\text { DV }\end{array}$ \\
Daun telah tua seluruhnya, keras, warna hijau gelap, dan panjang batang tunas $>5 \mathrm{~cm}$.
\end{tabular}

lainnya sehingga dianggap sebagai angkatan tunas utama. Pengamatan KLJ pada P8, P9, P10, P11, dan P12 dilakukan pada angkatan tunas utama masing-masing pada tunas SI, SII, SIII, SIV, dan SV. Pada pengamatan P10-P12, pengamatan KLJ juga dilakukan pada tunas kategori lainnya, yaitu SI-SV.

Di setiap kebun, kelimpahan KLJ diamati pada sepuluh pohon sampel acak sistematis. Pada setiap pohon, pengamatan dilakukan pada delapan tunas, yaitu dua tunas pada setiap kuadran kanopi di arah tenggara, barat daya, timur laut, dan barat laut. Kelimpahan KLJ diamati secara visual. Pengamatan telur dan nimfa KLJ menggunakan lensa genggam 10X dan nimfa tidak dibedakan antar instar (Sétamou et al. 2008).

\section{Pengamatan keanekaragaman dan kelimpahan artropoda musuh alami}

Pengamatan keanekaragaman dan kelimpahan artropoda musuh alami pada kanopi jeruk dilakukan satu kali sebelum perlakuan dan lima kali setelah perlakuan. Pengamatan setelah perlakuan dilakukan seminggu sekali setelah pengamatan KLJ pada periode pertunasan. Pada setiap pengamatan, artropoda dikumpulkan dari 6 pohon sampel acak per kebun. Artropoda musuh alami dikumpulkan melalui pengabutan insektisida piretroid yang bersifat knockdown (Ozanne 2005). Pengabutan dilakukan pada bagian dalam dan luar kanopi pohon sampel pada pukul 06.00-08.00. Dua lembar terpal plastik masingmasing berukuran $4 \mathrm{~m} \times 2 \mathrm{~m}$ dipasang di bawah kanopi jeruk dan dibiarkan terpasang selama 1 jam setelah pengabutan untuk menampung artropoda yang jatuh setelah terpapar insektisida (Turner \& Foster 2009). Artropoda yang terkumpul dimasukkan ke dalam botol koleksi berisi alkohol $70 \%$ menggunakan kuas halus (Ozanne 2005).

Spesimen artropoda dibawa ke Laboratorium Hama Tumbuhan, Universitas Brawijaya untuk identifikasi dan penghitungan kelimpahan musuh alami KLJ. Identifikasi artropoda berdasarkan karakter morfologi menggunakan literatur yang tersedia (Jocqué \& Dippenaar-Schoeman 2007; Triplehorn \& Johnson 2005). Penentuan suatu artropoda sebagai musuh alami KLJ berdasarkan literatur tentang predator, parasitoid, dan hiperparasitoid spesialis KLJ maupun generalis (Kondo et al. 2015).

\section{Pengamatan kejadian dan intensitas HLB}

Kejadian dan intensitas HLB diamati sebelum dan setelah perlakuan terhadap semua pohon jeruk di setiap kebun. Dalam pengamatan intensitas HLB, kanopi jeruk dibagi dua untuk membedakan bagian atas dan bawah kanopi. Kanopi jeruk kemudian dibagi lagi menjadi 4 kuadran sehingga setiap kanopi terbagi menjadi delapan bagian (Gottwald et al. 2007). Penilaian intensitas HLB di setiap bagian berdasarkan perkiraan persentase luas daun bergejala HLB menggunakan skala skor 0-4 dengan ketentuan skor 0 tanpa gejala HLB, sedangkan skor $1 ; 2 ; 3$; dan 4 masing-masing terdapat gejala HLB $1-25 ; 26-50 ; 51-75$; dan $>75 \%$. Rata-rata skor HLB setiap bagian kanopi ditentukan sebagai intensitas HLB pada masingmasing kebun. Kejadian HLB dihitung sebagai proporsi pohon jeruk bergejala HLB dari total pohon di kebun (Rasowo et al. 2019).

\section{Analisis data}

Kelimpahan KLJ antar perlakuan dibandingkan melalui Wilcoxon rank sum test karena datanya 
tidak berdistribusi normal. Pada setiap perlakuan, kelimpahan KLJ antar pengamatan dibandingkan melalui Friedman rank sum test dan jika terdapat perbedaan dilanjutkan dengan uji beda nyata terkecil. Kelimpahan musuh alami serta kejadian dan intensitas HLB antar perlakuan dibandingkan menggunakan $t$-test, kecuali total musuh alami setelah perlakuan yang datanya tidak berdistribusi normal dibandingkan dengan Wilcoxon rank sum test. Kejadian dan intensitas HLB sebelum dan setelah perlakuan dibandingkan dengan menggunakan paired t-test. Analisis data menggunakan software R v.4.0.2 (R Core Team 2020) dan SigmaPlot v.12.0 (Systat Software 2011). Indeks keanekaragaman Shannon-Wiener, kemerataan, dan dominansi Simpson's spesies musuh alami dihitung menggunakan vegan package v.2.5-6 (Oksanen et al. 2019).

\section{HASIL}

\section{Kelimpahan KLJ}

Sejak pengamatan P7 hingga P14, kecuali pada P12, minimal salah satu dari kelimpahan telur, nimfa, ataupun imago KLJ pada perlakuan pengelolaan agroekosistem lebih rendah dibandingkan dengan pertanian konvensional. Rerata kelimpahan KLJ sebelum, selama, dan setelah periode pertunasan maupun rerata dari seluruh pengamatan lebih rendah pada perlakuan pengelolaan agroekosistem dibandingkan dengan pertanian konvensional $(\mathrm{P}<0,05)$, kecuali rerata kelimpahan telur sebelum periode pertunasan $(\mathrm{P}>$ 0,05) (Tabel 3). Kelimpahan telur dan nimfa KLJ pada perlakuan pengelolaan agroekosistem juga tidak berfluktuasi secara signifikan, sedangkan kelimpahan imago sedikit berfluktuasi antar waktu

Tabel 3. Kelimpahan kutu loncat jeruk pada perlakuan pengelolaan agroekosistem dan pertanian konvensional

\begin{tabular}{|c|c|c|c|c|c|c|c|}
\hline \multirow{2}{*}{ Pengamatan } & \multirow{2}{*}{$\begin{array}{l}\text { Kategori } \\
\text { tunas }\end{array}$} & \multicolumn{2}{|c|}{$\begin{array}{l}\text { Jumlah telur per pohon } \\
\qquad(\overline{\mathrm{x}} \pm \mathrm{SD})\end{array}$} & \multicolumn{2}{|c|}{$\begin{array}{l}\text { Jumlah nimfa per pohon } \\
\qquad(\overline{\mathrm{x}} \pm \mathrm{SD})\end{array}$} & \multicolumn{2}{|c|}{$\begin{array}{l}\text { Jumlah imago per pohon } \\
\qquad(\overline{\mathrm{x}} \pm \mathrm{SD})\end{array}$} \\
\hline & & $\begin{array}{l}\text { Pengelolaan } \\
\text { agroekosistem }\end{array}$ & $\begin{array}{l}\text { Pertanian } \\
\text { konvensional }\end{array}$ & $\begin{array}{c}\text { Pengelolaan } \\
\text { agroekosistem }\end{array}$ & $\begin{array}{c}\text { Pertanian } \\
\text { konvensional }\end{array}$ & $\begin{array}{c}\text { Pengelolaan } \\
\text { agroekosistem }\end{array}$ & $\begin{array}{c}\text { Pertanian } \\
\text { konvensional }\end{array}$ \\
\hline \multicolumn{8}{|c|}{ Sebelum periode pertunasan } \\
\hline $\mathrm{P} 1$ & SI-SV & $1,23 \pm 4,99 \mathrm{a}$ & $0,93 \pm 3,34 \mathrm{a}$ & $0,43 \pm 1,52 \mathrm{a}$ & $1,13 \pm 3,10 \mathrm{a}$ & $1,10 \pm 1,77 \mathrm{a}$ & $1,30 \pm 2,05 \mathrm{a}$ \\
\hline $\mathrm{P} 2$ & SI-SV & $0,00 \pm 0,00 \mathrm{a}$ & $0,07 \pm 0,37 \mathrm{a}$ & $0,63 \pm 3,47 \mathrm{a}$ & $0,57 \pm 2,56 \mathrm{a}$ & $0,27 \pm 0,83 \mathrm{a}$ & $0,70 \pm 1,37 \mathrm{a}$ \\
\hline P3 & SI-SV & $0,00 \pm 0,00 \mathrm{a}$ & $0,07 \pm 0,37 \mathrm{a}$ & $0,33 \pm 1,09 \mathrm{a}$ & $1,33 \pm 4,47 \mathrm{a}$ & $0,63 \pm 1,61 \mathrm{a}$ & $0,23 \pm 0,82 \mathrm{a}$ \\
\hline P4 & SI-SV & $0,00 \pm 0,00 \mathrm{a}$ & $0,00 \pm 0,00 \mathrm{a}$ & $0,10 \pm 0,40 \mathrm{a}$ & $0,27 \pm 0,98 \mathrm{a}$ & $0,07 \pm 0,25 \mathrm{a}$ & $0,23 \pm 0,57 \mathrm{a}$ \\
\hline P5 & SI-SV & $0,00 \pm 0,00 \mathrm{a}$ & $0,07 \pm 0,37 \mathrm{a}$ & $0,60 \pm 3,10 \mathrm{a}$ & $1,10 \pm 3,21 \mathrm{a}$ & $0,03 \pm 0,18 \mathrm{a}$ & $0,47 \pm 1,61 \mathrm{a}$ \\
\hline P6 & SI-SV & $0,00 \pm 0,00 \mathrm{a}$ & $0,00 \pm 0,00 \mathrm{a}$ & $0,03 \pm 0,18 \mathrm{a}$ & $1,17 \pm 3,80 \mathrm{a}$ & $0,07 \pm 0,37 \mathrm{a}$ & $0,90 \pm 3,38 a$ \\
\hline P7 & SI-SV & $0,00 \pm 0,00 \mathrm{a}$ & $1,00 \pm 5,48 \mathrm{a}$ & $0,20 \pm 1,10 \mathrm{a}$ & $0,50 \pm 1,64 \mathrm{a}$ & $0,23 \pm 1,28 \mathrm{a}$ & $1,47 \pm 5,68 b$ \\
\hline Rerata P1-P & & $0,18 \pm 1,91 \mathrm{a}$ & $0,30 \pm 2,44 \mathrm{a}$ & $0,33 \pm 1,93 \mathrm{a}$ & $0,87 \pm 3,02 b$ & $0,34 \pm 1,13 \mathrm{a}$ & $0,76 \pm 2,76 b$ \\
\hline \multicolumn{8}{|c|}{ Selama periode pertunasan } \\
\hline P8 & SI & $0,00 \pm 0,00 \mathrm{a}$ & $0,67 \pm 3,65 \mathrm{a}$ & $0,00 \pm 0,00 \mathrm{a}$ & $3,60 \pm 11,58 b$ & $0,17 \pm 0,91 \mathrm{a}$ & $1,63 \pm 3,56 b$ \\
\hline P9 & SII & $0,00 \pm 0,00 \mathrm{a}$ & $0,17 \pm 0,91 \mathrm{a}$ & $0,00 \pm 0,00 \mathrm{a}$ & $0,97 \pm 2,41 \mathrm{~b}$ & $0,00 \pm 0,00 \mathrm{a}$ & $1,03 \pm 2,24 b$ \\
\hline \multirow[t]{2}{*}{ P10 } & SIII & $0,00 \pm 0,00 \mathrm{a}$ & $0,00 \pm 0,00 \mathrm{a}$ & $0,13 \pm 0,43 \mathrm{a}$ & $0,60 \pm 2,08 \mathrm{a}$ & $0,07 \pm 0,25 \mathrm{a}$ & $0,30 \pm 0,84 \mathrm{a}$ \\
\hline & SI-SV & $0,00 \pm 0,00 \mathrm{a}$ & $1,90 \pm 5,71 \mathrm{~b}$ & $0,37 \pm 1,10 \mathrm{a}$ & $2,63 \pm 5,82 \mathrm{~b}$ & $0,20 \pm 0,48 \mathrm{a}$ & $0,67 \pm 1,24 \mathrm{a}$ \\
\hline \multirow[t]{2}{*}{ P11 } & SIV & $0,00 \pm 0,00 \mathrm{a}$ & $0,00 \pm 0,00 \mathrm{a}$ & $0,00 \pm 0,00 \mathrm{a}$ & $0,70 \pm 1,66 \mathrm{~b}$ & $0,00 \pm 0,00 \mathrm{a}$ & $1,27 \pm 2,74 b$ \\
\hline & SI-SV & $0,00 \pm 0,00 \mathrm{a}$ & $0,47 \pm 1,28 \mathrm{~b}$ & $0,00 \pm 0,00 \mathrm{a}$ & $4,77 \pm 8,92 \mathrm{~b}$ & $0,03 \pm 0,18 \mathrm{a}$ & $1,57 \pm 3,70 b$ \\
\hline \multirow[t]{2}{*}{$\mathrm{P} 12$} & SV & $0,00 \pm 0,00 \mathrm{a}$ & $0,00 \pm 0,00 \mathrm{a}$ & $0,10 \pm 0,55 \mathrm{a}$ & $0,27 \pm 0,74 \mathrm{a}$ & $0,20 \pm 0,55 \mathrm{a}$ & $1,50 \pm 3,08 \mathrm{a}$ \\
\hline & SI-SV & $0,10 \pm 0,55 \mathrm{a}$ & $0,00 \pm 0,00 \mathrm{a}$ & $1,30 \pm 3,54 \mathrm{a}$ & $0,73 \pm 1,34 \mathrm{a}$ & $0,40 \pm 0,89 \mathrm{a}$ & $3,20 \pm 6,52 a$ \\
\hline \multicolumn{2}{|c|}{ Rerata P8-P12 } & $0,02 \pm 0,24 \mathrm{a}$ & $0,64 \pm 3,14 \mathrm{~b}$ & $0,33 \pm 1,71 \mathrm{a}$ & $2,54 \pm 7,22 b$ & $0,16 \pm 0,62 \mathrm{a}$ & $1,62 \pm 3,93 b$ \\
\hline \multicolumn{8}{|c|}{ Setelah periode pertunasan } \\
\hline P13 & SI-SV & $0,00 \pm 0,00 \mathrm{a}$ & $0,00 \pm 0,00 \mathrm{a}$ & $0,17 \pm 0,65 \mathrm{a}$ & $0,53 \pm 0,97 \mathrm{~b}$ & $0,43 \pm 1,52 \mathrm{a}$ & $1,83 \pm 2,79 b$ \\
\hline P14 & SI-SV & $0,00 \pm 0,00 \mathrm{a}$ & $3,60 \pm 8,00 \mathrm{~b}$ & $0,00 \pm 0,00 \mathrm{a}$ & $2,63 \pm 4,77 \mathrm{~b}$ & $0,10 \pm 0,40 \mathrm{a}$ & $1,30 \pm 2,00 \mathrm{~b}$ \\
\hline \multicolumn{2}{|c|}{ Rerata P13-P14 } & $0,00 \pm 0,00 \mathrm{a}$ & $1,80 \pm 5,89 \mathrm{~b}$ & $0,08 \pm 0,46 \mathrm{a}$ & $1,58 \pm 3,58 \mathrm{~b}$ & $0,27 \pm 1,12 \mathrm{a}$ & $1,57 \pm 2,42 b$ \\
\hline \multicolumn{2}{|c|}{$\begin{array}{l}\text { Rerata seluruh } \\
\text { pengamatan (P1-P14) }\end{array}$} & $0,10 \pm 1,36 \mathrm{a}$ & $0,64 \pm 3,41 b$ & $0,30 \pm 1,71 \mathrm{a}$ & $1,57 \pm 5,04 b$ & $0,27 \pm 0,98 \mathrm{a}$ & $1,18 \pm 3,21 b$ \\
\hline
\end{tabular}

Angka yang diikuti oleh huruf yang sama pada baris yang sama pada setiap kolom fase perkembangan kutu loncat jeruk yang sama menunjukkan tidak berbeda nyata pada $\mathrm{P}<0,05$. 
A

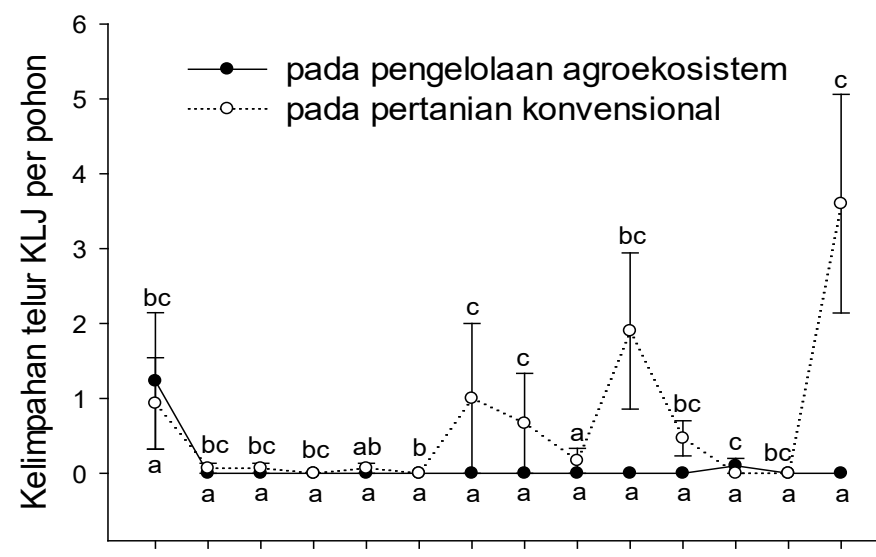

$\begin{array}{llllllllllllll}\text { P1 } & \text { P2 } & \text { P3 } & \text { P4 } & \text { P5 } & \text { P6 } & \text { P7 } & \text { P8 } & \text { P9 P10 P11 P12 P13 P14 }\end{array}$

Pengamatan

B

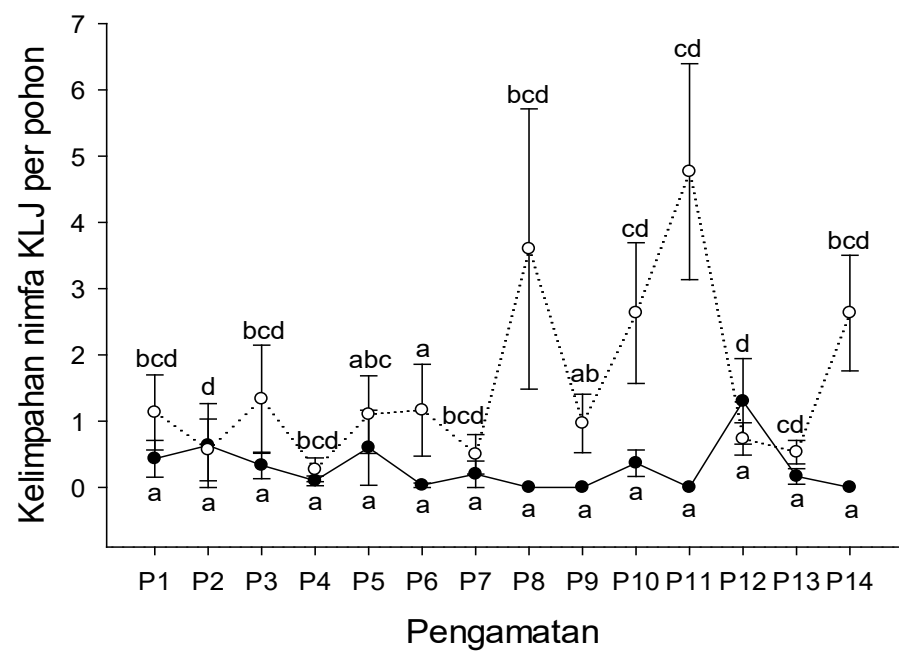

$\mathrm{C}$

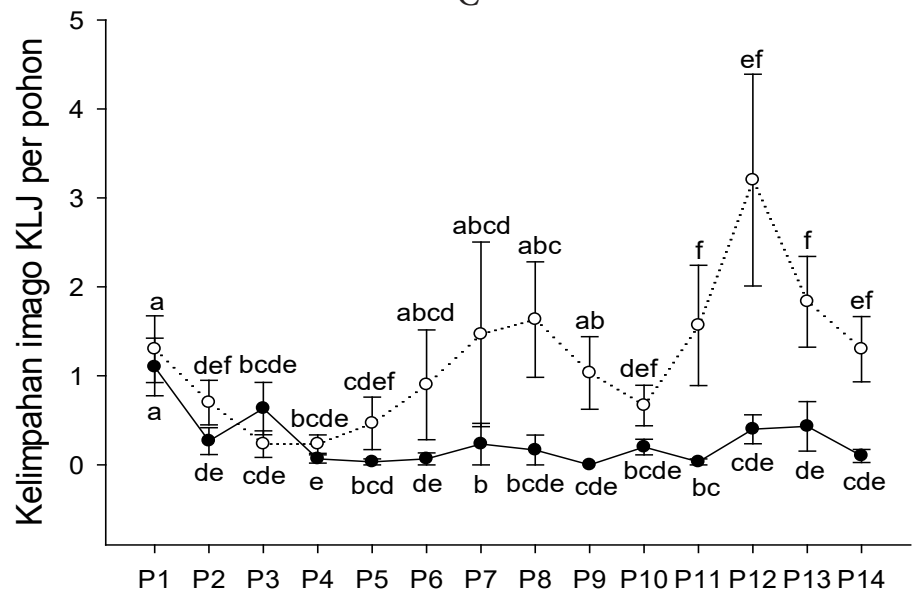

Pengamatan

Gambar 1. Kelimpahan A: telur; B: nimfa; dan C: imago kutu loncat jeruk (KLJ) pada perlakuan pengelolaan agroekosistem dan pertanian konvensional. Kelimpahan KLJ pada P8 dan P9 masing-masing pada tunas SI dan SII, sedangkan pengamatan lainnya pada tunas SI-SV. Kelimpahan KLJ yang diikuti huruf superskrip yang sama pada perlakuan yang sama tidak berbeda nyata pada $\mathrm{P}<0,05$. Posisi huruf superskrip pada perlakuan pengelolaan agroekosistem di bawah garis, sedangkan pada pertanian konvensional di atas garis. 
pengamatan. Sebaliknya, kelimpahan telur, nimfa, maupun imago KLJ pada pertanian konvensional lebih berfluktuasi antar waktu pengamatan (Gambar 1).

\section{Keanekaragaman dan kelimpahan artropoda musuh alami KLJ}

Sebanyak 19.952 individu musuh alami KLJ ditemukan yang terdiri atas 16.443 individu dari Kelas Insekta dan 3.509 individu dari Kelas Arachnida. Musuh alami KLJ dari Kelas Insekta tergolong dalam lima ordo, yaitu Hymenoptera, Coleoptera, Diptera, Neuroptera, dan Mantodea, sedangkan dari Kelas Arachnida hanya terdiri atas Subkelas Araneae. Kelimpahan musuh alami KLJ pada perlakuan pengelolaan agroekosistem tidak berbeda nyata dengan pertanian konvensional
(Tabel 4). Namun, rerata indeks keanekaragaman dan kemerataan spesies musuh alami KLJ pada perlakuan pengelolaan agroekosistem lebih tinggi dibandingkan dengan pertanian konvensional. Sebaliknya, rerata indeks dominansi spesies musuh alami KLJ pada perlakuan pengelolaan agroekosistem lebih rendah dibandingkan dengan pertanian konvensional (Tabel 5).

\section{Kejadian dan intensitas HLB}

Kejadian dan intensitas HLB pada perlakuan pengelolaan agroekosistem dan pertanian konvensional tidak berbeda nyata, baik sebelum maupun setelah perlakuan $(\mathrm{P}>0,05)$. Pada masingmasing perlakuan, tingkat kejadian dan intensitas HLB setelah perlakuan tidak berubah signifikan dibandingkan sebelum perlakuan (Tabel 6).

Tabel 4. Kelimpahan musuh alami kutu loncat jeruk

\begin{tabular}{lccccc}
\hline \multirow{2}{*}{ Kelas } & \multicolumn{2}{c}{ Sebelum perlakuan $(\overline{\mathrm{x}} \pm \mathrm{SD})$} & & \multicolumn{2}{c}{ Setelah perlakuan $(\overline{\mathrm{x}} \pm \mathrm{SD})$} \\
\cline { 2 - 3 } \cline { 6 - 6 } & $\begin{array}{c}\text { Pengelolaan } \\
\text { agroekosistem }\end{array}$ & $\begin{array}{c}\text { Pertanian } \\
\text { konvensional }\end{array}$ & & $\begin{array}{c}\text { Pengelolaan } \\
\text { agroekosistem }\end{array}$ & $\begin{array}{c}\text { Pertanian } \\
\text { konvensional }\end{array}$ \\
\hline Insekta & $204,67 \pm 36,83$ & $1.276,33 \pm 1.717,72$ & & $1.159,67 \pm 1.141,32$ & $2.840,33 \pm 3.603,44$ \\
Arachnida & $144,33 \pm 17,79$ & $204,00 \pm 90,15$ & & $484,67 \pm 144,98$ & $336,67 \pm 106,03$ \\
\hline Total & $349,00 \pm 54,03$ & $1.480,33 \pm 1.722,34$ & & $1.644,33 \pm 1.019,95$ & $3.177,00 \pm 3.591,99$ \\
\hline
\end{tabular}

Tabel 5. Indeks keanekaragaman, kemerataan, dan dominansi spesies musuh alami kutu loncat jeruk

\begin{tabular}{lcc}
\hline Pengamatan & $\begin{array}{c}\text { Pengelolaan agroekosistem } \\
(\overline{\mathrm{x}} \pm \mathrm{SD})\end{array}$ & $\begin{array}{c}\text { Pertanian konvensional } \\
(\overline{\mathrm{x}} \pm \mathrm{SD})\end{array}$ \\
\hline $\begin{array}{l}\text { Indeks keanekaragaman Shannon-Wiener (H') } \\
\quad \text { Sebelum perlakuan }\end{array}$ & $1,91 \pm 0,26$ & $1,44 \pm 0,76$ \\
$\quad$ Setelah perlakuan & $2,19 \pm 0,50$ & $1,58 \pm 0,66$ \\
$\quad$ Indeks kemerataan (E) & & \\
$\quad$ Sebelum perlakuan & $0,73 \pm 0,11$ & $0,53 \pm 0,30$ \\
$\quad$ Setelah perlakuan & $0,69 \pm 0,15$ & $0,51 \pm 0,19$ \\
Indeks dominansi Simpson's (D) & & \\
$\quad$ Sebelum perlakuan & $0,23 \pm 0,08$ & $0,43 \pm 0,32$ \\
$\quad$ Setelah perlakuan & $0,20 \pm 0,15$ & $0,38 \pm 0,22$ \\
\hline
\end{tabular}

Tabel 6. Kejadian dan intensitas penyakit huanglongbing (HLB)

\begin{tabular}{lcc}
\hline Pengamatan & $\begin{array}{c}\text { Pengelolaan agroekosistem } \\
(\overline{\mathrm{x}} \pm \mathrm{SD})\end{array}$ & $\begin{array}{c}\text { Pertanian konvensional } \\
(\overline{\mathrm{x}} \pm \mathrm{SD})\end{array}$ \\
\hline Kejadian HLB (\%) & & $78,18 \pm 8,10$ \\
$\quad$ Sebelum perlakuan & $62,46 \pm 28,23$ & $81,08 \pm 21,29$ \\
$\quad$ Setelah perlakuan & $84,62 \pm 5,46$ & \\
Skor intensitas HLB & & $0,54 \pm 0,14$ \\
$\quad$ Sebelum perlakuan & $0,50 \pm 0,50$ & $0,85 \pm 0,57$ \\
$\quad$ Setelah perlakuan & $0,66 \pm 0,36$ & \\
\hline
\end{tabular}




\section{PEMBAHASAN}

Kelimpahan KLJ pada perlakuan pengelolaan agroekosistem lebih rendah dibandingkan dengan pertanian konvensional sejak pengamatan P7 (Tabel 3). Hal ini diduga terkait dengan tumbuhnya tunas baru tanaman jeruk. Meskipun tunas utama baru tumbuh 1-7 hari sebelum P8, namun pada P7 juga telah tumbuh sedikit tunas baru. Kelimpahan KLJ pada pertanian konvensional cenderung meningkat seiring tumbuhnya tunas baru. Hal tersebut sejalan dengan laporan Tsai et al. (2002) bahwa populasi KLJ berkorelasi positif dengan ketersediaan tunas baru. Sementara pada perlakuan pengelolaan agroekosistem, tumbuhnya tunas baru tidak meningkatkan kelimpahan telur maupun nimfa KLJ dan hanya sedikit meningkatkan kelimpahan imago KLJ pada awal pertunasan. Hal ini diduga disebabkan tindakan preventif penambahan keanekaragaman vegetasi telah meningkatkan keanekaragaman musuh alami pada perlakuan pengelolaan agroekosistem. Tindakan tersebut menyebabkan musuh alami pada perlakuan pengelolaan agroekosistem lebih beragam dibandingkan dengan pertanian konvensional (Tabel 5). Musuh alami yang lebih beragam diduga menyebabkan kematian KLJ yang lebih banyak sehingga kelimpahannya cenderung tidak meningkat meskipun tunas baru tanaman jeruk tersedia. Hal ini sejalan dengan laporan Elek et al. (2020) bahwa lanskap yang lebih kompleks dapat meningkatkan komunitas serangga predator dan mengurangi kelimpahan aphid.

Kelimpahan KLJ pada perlakuan pengelolaan agroekosistem kurang berfluktuasi dibandingkan dengan pertanian konvensional (Gambar 1). Hal ini menunjukkan pengelolaan agroekosistem dapat meredam ledakan populasi KLJ sekaligus menunjukkan potensi terjadinya ledakan populasi vektor ini jika dikendalikan secara konvensional.

Pengelolaan agroekosistem yang lebih efektif dibandingkan dengan pertanian konvensional dalam mengendalikan populasi KLJ merupakan dampak dari berbagai tindakan preventif (Tabel 1). Tindakan preventif yang diduga menurunkan kelimpahan KLJ adalah peningkatan keanekaragaman vegetasi yang meliputi sistem tanam polikultur, penanaman refugia dan legum penutup tanah, penyediaan jalur rumput, serta 110 pengendalian gulma yang masih menyisakan rumput di kebun. Keanekaragaman vegetasi yang lebih tinggi diduga menyebabkan musuh alami KLJ lebih beragam pada perlakuan pengelolaan agroekosistem (Tabel 5). Hasil ini sejalan dengan laporan Ashraf et al. (2018) bahwa jumlah ordo dan famili artropoda lebih tinggi pada kebun kelapa sawit polikultur dibandingkan dengan monokultur. Eulophid Tamarixia radiata (Waterston) dan syrphid Dideopsis aegrota (Fabricius) yang hanya ditemukan pada perlakuan pengelolaan agroekosistem dapat menambah kematian KLJ. Oleh karena itu, musuh alami yang lebih beragam pada perlakuan pengelolaan agroekosistem diduga menyebabkan kematian KLJ yang lebih banyak sehingga kelimpahan KLJ lebih rendah dibandingkan dengan pertanian konvensional. Hal ini selaras dengan pernyataan Stelinski (2019) bahwa kompleksitas habitat mempengaruhi kepadatan KLJ.

Tanaman tumpang sari buncis dan kacang tunggak tampaknya dapat mempertahankan populasi T. radiata. Sebelum perlakuan, parasitoid KLJ ini ditemukan pada kedua perlakuan. Namun, setelah perlakuan $T$. radiata hanya ditemukan pada perlakuan pengelolaan agroekosistem. Hal ini mungkin disebabkan makanan T. radiata tersedia pada perlakuan pengelolaan agroekosistem yang berasal dari ekstrafloral bunga buncis dan kacang tunggak, sementara pada pertanian konvensional makanan tersebut tidak tersedia. Menurut Patt \& Rohrig (2017), ekstrafloral yang terbuka pada bunga buncis dan kacang tunggak lebih mudah didapatkan T. radiata.

Penanaman rufugia dapat meningkatkan ketersediaan nektar, polen, dan inang alternatif bagi berbagai musuh alami. Oleh karena itu, penanaman bunga matahari dan kenikir pada pengelolaan agroekosistem diduga meningkatkan keanekaragaman musuh alami KLJ. Kurniawati (2015) juga melaporkan penanaman tumbuhan berbunga pada tanaman padi meningkatkan keanekaragaman artropoda termasuk serangga musuh alami.

Penanaman legum penutup tanah, penyediaan jalur rumput, serta pengendalian gulma yang masih menyisakan rumput dalam pengelolaan agroekosistem dapat menyediakan tempat berlindung ataupun makanan bagi musuh alami. 
Pada pertanian konvensional, kebun diupayakan bersih dari gulma melalui penyemprotan herbisida maupun pengendalian mekanis. Gulma yang disemprot herbisida akan mati dan memerlukan waktu relatif lama untuk tumbuh kembali sehingga mengurangi habitat musuh alami. Oleh karena itu, penanaman legum penutup tanah serta pengelolaan gulma yang lebih baik pada perlakuan pengelolaan agroekosistem diduga menyebabkan musuh alami KLJ lebih beragam dibandingkan dengan pertanian konvensional. Hal ini sejalan dengan laporan Daniati et al. (2018) bahwa gulma A. pintoi, Ageratum conyzoides L. (Asteraceae), dan Synedrela nodiflora (L.) Gaertn. (Asteraceae) sebagai penutup tanah meningkatkan jumlah spesies serta populasi predator dan parasitoid pada kebun kopi.

Kelimpahan musuh alami KLJ yang tidak berbeda nyata antar perlakuan diduga disebabkan masa penelitian relatif singkat. Periode waktu 2-3 bulan sejak dimulainya pengelolaan agroekosistem hingga pengamatan mungkin terlalu singkat untuk proses suksesi musuh alami. Ashraf et al. (2018) melaporkan kelimpahan artropoda, predator, dan dekomposer pada kebun kelapa sawit polikultur lebih tinggi daripada monokultur ketika lima jenis tanaman tumpang sari berumur 1-6 tahun. Dari umur tanaman tumpangsari tersebut, tampak bahwa peningkatan kelimpahan artropoda, predator, dan dekomposer terjadi dalam waktu yang lebih lama dibandingkan dengan masa penerapan pengelolaan agroekosistem dalam penelitian ini. Oleh karena itu, peningkatan keanekaragaman vegetasi sebaiknya dilakukan sejak tahapan awal budi daya jeruk.

Spesies musuh alami KLJ pada perlakuan pengelolaan agroekosistem lebih beragam dan merata kelimpahannya daripada pertanian konvensional (Tabel 5). Selain keanekaragaman vegetasi yang lebih tinggi, musuh alami yang lebih beragam pada perlakuan pengelolaan agroekosistem diduga juga disebabkan oleh penggunaan insektisida yang lebih rendah. Pada perlakuan pengelolaan agroekosistem, insektisida hanya digunakan ketika kelimpahan KLJ mencapai ambang tindakannya. Selama penelitian, penyemprotan insektisida hanya satu kali pada dua kebun perlakuan pengelolaan agroekosistem, sementara satu kebun lainnya tanpa insektisida. Sementara itu, penyemprotan insektisida pada pertanian konvensional masing-masing dua kali pada dua kebun serta satu kali pada satu kebun lainnya. Semakin jarang penyemprotan insektisida maka semakin sedikit serangga termasuk musuh alami yang terbunuh ataupun bermigrasi. Oleh karena itu, insektisida yang lebih jarang digunakan diduga menyebabkan musuh alami KLJ lebih beragam pada perlakuan pengelolaan agroekosistem daripada pertanian konvensional. Hal ini sesuai dengan laporan Monzo et al. (2014) bahwa penyemprotan insektisida berjadwal berdampak negatif terhadap populasi musuh alami yang mengakibatkan berkurangnya predasi pada nimfa KLJ.

Kejadian dan intensitas HLB yang tidak berbeda nyata antar perlakuan (Tabel 6) tampaknya disebabkan oleh waktu penelitian yang relatif singkat dibandingkan dengan masa inkubasi patogen HLB. Pengamatan kejadian dan intensitas HLB setelah perlakuan dilakukan sekitar 5 bulan setelah dimulainya penerapan perlakuan. Menurut Gottwald (2010), gejala HLB pada tanaman muda terlihat setelah 6-12 bulan, sedangkan pada tanaman berumur 7-10 tahun memerlukan waktu 1-2,5 tahun. Dengan demikian, gejala HLB yang terlihat pada pengamatan setelah perlakuan diduga sebagai gejala dari infeksi patogen HLB sebelum penelitian ini dimulai. Hal ini sesuai dengan hasil pengamatan kejadian dan intensitas HLB setelah perlakuanyang tidak berbeda nyata dengan sebelum perlakuan, baik pada perlakuan pengelolaan agroekosistem maupun pertanian konvensional (Tabel 6). Oleh karena itu, meskipun pengelolaan agroekosistem telah menurunkan populasi KLJ hingga kelimpahannya lebih rendah dibandingkan dengan pertanian konvensional, namun perlakuan tersebut tidak seketika menyebabkan perbedaan tingkat serangan HLB. Perbedaan efektivitas kedua perlakuan terhadap kejadian dan intensitas HLB sebagai dampak lanjutan dari perbedaan kelimpahan KLJ mungkin akan terlihat pada waktu yang lebih lama dibandingkan dengan masa penelitian ini, tergantung pada masa inkubasi patogen HLB dalam tanaman jeruk. Oleh sebab itu, penilaian efektivitas perlakuan terhadap kejadian dan intensitas HLB di masa mendatang sebaiknya dilakukan dalam kurun waktu yang memadai dengan mempertimbangkan masa inkubasi patogen HLB dalam tanaman. 


\section{KESIMPULAN}

Perlakuan pengelolaan agroekosistem lebih efektif mengendalikan populasi KLJ hingga kelimpahannya lebih rendah dan kurang berfluktuasi dibandingkan dengan pertanian konvensional. Musuh alami KLJ pada perlakuan pengelolaan agroekosistem lebih beragam dibandingkan dengan pertanian konvensional. Kelimpahan musuh alami KLJ serta kejadian dan intensitas HLB pada perlakuan pengelolaan agroekosistem dan pertanian konvensional tidak berbeda nyata.

\section{UCAPAN TERIMA KASIH}

Penelitian ini didanai oleh Badan Penelitian dan Pengembangan Pertanian. Kami berterima kasih kepada Yogo Setiawan atas bantuan identifikasi artropoda musuh alami.

\section{DAFTAR PUSTAKA}

Altieri MA, Nicholls CI. 2005. Agroecology and the Search for a Truly Sustainable Agriculture. $1^{\text {st }}$ edition. Mexico: United Nations Environment Programme Environmental Training Network for Latin America and The Carribean.

Arredondo IMJ. 2009. Abundance and Population Dynamics of the Asian Citrus Psyllid Diaphorina citri Kuwayama (Hemiptera: Psyllidae) as Affected by Flush Shoots in Different Host Plants. Thesis. Kingsville: Texas A\&M UniversityKingsville.

Ashraf M, Zulkifli R, Sanusi R, Tohiran KA, Terhem R, Moslim R, Norhisham AR, Ashton-Butt A, Azhar B. 2018. Alley-cropping system can boost arthropod biodiversity and ecosystem functions in oil palm plantations. Agriculture, Ecosystems and Environment 260:19-26. doi: https://doi. org/10.1016/j.agee.2018.03.017.

Bassanezi RB, Lopes SA, de Miranda MP, Wulff NA, Volpe HXL, Ayres AJ. 2020. Overview of citrus huanglongbing spread and management strategies in Brazil. Tropical Plant Pathology 45:251-264. doi: https://doi.org/10.1007/ s40858-020-00343-y.

BMKG. 2020. Laporan iklim harian pada Stasiun Meteorologi Paloh. Tersedia pada: http:// dataonline.bmkg.go.id [diakses 25 May 2020].
Bové JM. 2006. Huanglongbing: a destructive, newly-emerging, century-old disease of citrus. Journal of Plant Pathology 88:7-37.

Burckhardt D, Ouvrard D. 2012. A revised classification of the jumping plant-lice (Hemiptera: Psylloidea). Zootaxa 3509:1-34. doi: https://doi.org/10.11646/zootaxa.3509.1.1.

Daniati C, Karindah S, Puspitarini RD. 2018. Three species of weeds enhance the population of predator and parasitoid of coffee berry borers. Biosaintifika 10:229-236. doi: https://doi. org/10.15294/biosaintifika.v10i1.12076.

Dufour R. 2001. Biointensive Integrated Pest Management (IPM). Fayetteville: Appropriate Technology Transfer for Rural Areas (ATTRA).

Elek Z, Růžičková J, Ádám R, Bereczki K, Boros G, Kádár F, Kovács-Hostyánszki A, Somay L, Szalkovszki O, Báldi A. 2020. Mixed effects of ecological intensification on natural pest control providers: a short-term study for biotic homogenization in winter wheat fields. PeerJ 8:1-18. doi: https://doi.org/10.7717/peerj.8746.

Endarto O, Supriyanto A, Wuryantini S, Triwiratno A. 2006. Evaluasi penerapan pengelolaan terpadu kebun jeruk sehat (PTKJS) pada daerah endemis CVPD. Di dalam: Winarno M, Supriyanto A, Dwiastuti ME, Setyobudi L (Eds.) Prosiding Seminar Nasional Jeruk Tropika Indonesia. (Batu, 28-29 Juli 2005). hlm. 277-295. Jakarta: Pusat Penelitian dan Pengembangan Hortikultura.

Gottwald TR. 2010. Current epidemiological understanding of citrus huanglongbing. Annual Review of Phytopathology 48:119139. doi: https://doi.org/10.1146/annurevphyto-073009-114418.

Gottwald TR, da Graça JV, Bassanezi RB. 2007. Citrus huanglongbing: the pathogen and its impact. Plant Health Progress 8:1-35. doi: https://doi.org/10.1094/PHP-2007-0906-01-RV.

Iftikhar Y, Rauf S, Shahzad U, Zahid MA. 2016. Huanglongbing: pathogen detection system for integrated disease management - a review. Journal of the Saudi Society of Agricultural Sciences 15:1-11. doi: https://doi.org/10.1016/j. jssas.2014.04.006.

Jocqué R, Dippenaar-Schoeman AS. 2007. Spider Families of the World. $2^{\text {nd }}$ edition. Tervuren: Musée Royal de L'Afrique Centrale.

Joubert FJ, Stassen PJC. 2000. The effect of time of pruning on yield, fruit size and greening disease incidence of Valencia Citrus trees. Neltropika 309:28-31. 
Kondo T, González GF, Tauber C, Sarmiento YCG, Mondragon AFV, Forero D. 2015. A checklist of natural enemies of Diaphorina citri Kuwayama (Hemiptera: Liviidae) in the Department of Valle del Cauca, Colombia and the World. Insecta Mundi 457:1-14.

Kurniawati N. 2015. Keragaman dan kelimpahan musuh alami hama pada habitat padi yang dimanipulasi dengan tumbuhan berbunga. Ilmu Pertanian 18:31-36. doi: https://doi. org/10.22146/ipas.6175.

Lewis WJ, van Lenteren JC, Phatak SC, Tumlinson JH. 1997. A total system approach to sustainable pest management. Proceedings of the National Academy of Sciences of the United States of America 94:12243-12248. doi: https://doi. org/10.1073/pnas.94.23.12243.

Monzo C, Qureshi JA, Stansly PA. 2014. Insecticide sprays, natural enemy assemblages and predation on asian citrus psyllid, Diaphorina citri (Hemiptera: Psyllidae). Bulletin of Entomological Research 104:1-10. doi: https:// doi.org/10.1017/S0007485314000315.

Mudjiono G. 2013. Pengelolaan Hama Terpadu: Konsep, Taktik, Strategi, Penyusunan Program PHT, dan Implementasinya. Malang: UB Press.

Nurhadi. 2015. Penyakit huanglongbing tanaman jeruk (Candidatus Liberibacter asiaticus): ancaman dan strategi pengendalian. Pengembangan Inovasi Pertanian 8:21-32.

Nurindah. 2006. Pengelolaan agroekosistem dalam pengendalian hama. Perspektif 5:78-85.

Oksanen J, Blanchet FG, Friendly M, Kindt R, Legendre P, McGlinn D, Minchin PR, O’Hara RB, Simpson GL, Solymos P, Stevens MHH, Szoecs E, Wagner H. 2019. Vegan: community ecology package. $\mathrm{R}$ package version 2.5-6.

Ozanne CMP. 2005. Techniques and methods for sampling canopy insects. Di dalam: Leather SR (Ed.). Insect Sampling in Forest Ecosystems. hlm. 146-167. Oxford: Blackwell Science Ltd.

Patt JM, Rohrig E. 2017. Laboratory evaluations of the foraging success of Tamarixia radiata (Hymenoptera: Eulophidae) on flowers and extrafloral nectaries: potential use of nectar plants for conservation biological control of asian citrus psyllid (Hemiptera: Liviidae). Florida Entomologist 100:149-156. doi: https:// doi.org/10.1653/024.100.0121.

Pustika AB, Subandiyah S, Holford P, Beattie GAC, Iwanami T, Masaoka Y. 2008. Interactions between plant nutrition and symptom expression in Mandarin trees infected with the disease huanglongbing. Australasian Plant Disease Notes 3:112-115. doi: https://doi.org/10.1071/ DN08045.

R Core Team. 2020. R: a language and environment for statistical computing. Vienna: R Foundation for Statistical Computing.

Ramírez-Godoy A, Puentes-Pérez G, Restrepo-Díaz H. 2018. An evaluation of the use of calcium, potassium and silicon for the management of Diaphorina citri populations in Tahiti Lime trees. Notulae Botanicae Horti Agrobotanici Cluj-Napoca 46:546-552. doi: https://doi. org/10.15835/nbha46211152.

Rasowo BA, Khamis FM, Mohamed SA, Ajene IJ, Aidoo OF, Ombura L, Sétamou M, Ekesi S, Borgemeister C. 2019. African citrus greening disease in East Africa: incidence, severity, and distribution patterns. Journal of Economic Entomology 112:2389-2397. doi: https://doi. org/10.1093/jee/toz167.

Ratu S, Taufik M, Khaeruni A. 2020. Insidensi penyakit Citrus vein phloem degeneration (CVPD) dan kepadatan populasi serangga vektor Diaphorina citri pada tanaman jeruk di Pulau Siompu Kabupaten Buton Selatan. Jurnal Berkala Penelitian Agronomi 8:33-39.

Ridwan HK, Ruswandi A, Winarno, Muharam A, Hardiyanto. 2008. Sifat inovasi dan aplikasi teknologi pengelolaan terpadu kebun jeruk sehat dalam pengembangan agribisnis jeruk di Kabupaten Sambas, Kalimantan Barat. Jurnal Hortikultura 18:477-490.

Ridwan HK, Sabari, Rofik SB, Rahman S, Agus R. 2010. Adopsi inovasi teknologi pengelolaan terpadu kebun jeruk sehat (PTKJS) di Kabupaten Ponorogo, Jawa Timur. Jurnal Hortikultura 20:96-102.

Sétamou M, Flores D, French JV, Hall DG. 2008. Dispersion patterns and sampling plans for Diaphorina citri (Hemiptera: Psyllidae) in citrus. Journal of Economic Entomology 101:1478-1487. doi: https://doi.org/10.1093/ jee/101.4.1478.

Sétamou M, Simpson CR, Alabi OJ, Nelson SD, Telagamsetty S, Jifon JL. 2016. Quality matters: influences of citrus flush physicochemical characteristics on population dynamics of the asian citrus psyllid (Hemiptera: Liviidae). PLoS ONE 11:1-18. doi: https://doi.org/10.1371/ journal.pone.0168997.

Stelinski LL. 2019. Ecological aspects of the vector-borne bacterial disease, citrus greening (huanglongbing): dispersal and host use by asian 
citrus psyllid, Diaphorina citri Kuwayama. Insects 10:1-11. doi: https://doi.org/10.3390/ insects 10070208.

Supriyanto A, Dwiastuti ME, Triwiratno A, Endarto O, Suhariyono. 2010. Pengelolaan Terpadu Kebun Jeruk Sehat Strategi Pengendalian Penyakit CVPD. Batu: Balai Penelitian Tanaman Jeruk dan Buah Subtropika.

Supriyanto A, Zuhran M, Purbiati T. 2017. Effectiveness of huanglongbing vector (Diaphorina citri Kuwayama) control in citrus grower group based in Sambas Regency of West Kalimantan, Indonesia. RJOAS 12:320-326. doi: https://doi.org/10.18551/rjoas.2017-12.45.

Systat Software. 2011. Sigmaplot for windows version 12.0. San Jose: Systat Software, Inc.

Triplehorn, CA, Johnson NF. 2005. Borror and DeLong's Introduction to the Study of Insects. $7^{\text {th }}$ edition. Belmont: Thompson Brooks/Cole.

Tsai JH, Wang JJ, Liu YH. 2002. Seasonal abundance of the asian citrus psyllid, Diaphorina citri (Homoptera: Psyllidae) in Southern Florida. Florida Entomologist 85:446-451. doi: https:// doi.org/10.1653/0015-4040(2002)085[0446:SA OTAC]2.0.CO;2.
Turner EC, Foster WA. 2009. The impact of forest conversion to oil palm on arthropod abundance and biomass in Sabah, Malaysia. Journal of Tropical Ecology 25:23-30. doi: https://doi. org/10.1017/S0266467408005658.

Warda, Asaad M. 2008. Pengendalian terpadu vektor CVPD dan hama penyebab burik pada Jeruk Siem di Kabupaten Luwu Utara. Jurnal Pengkajian dan Pengembangan Teknologi Pertanian 11:156-163.

Wijaya IN, Sritamin M, Adnyana MM, Adiartayasa W, Bagus IGN. 2012. Pendidikan dan pelatihan pengendalian kutu loncat jeruk (Diaphorina citri Kuwayama) sebagai hama dan vektor penyakit CVPD di Desa Taro, Gianyar. Udayana Mengabdi 11:93-95.

Yang Y, Huang M, Beattie GAC, Xia Y, Ouyang G, Xiong J. 2006. Distribution, biology, ecology and control of the psyllid Diaphorina citri Kuwayama, a major pest of citrus: a status report for China. International Journal of Pest Management 52:343-352. doi: https://doi. org/10.1080/09670870600872994. 